\title{
Correlates of Fertility in a Low Contraception Setting: A Study of $O g u$ of South-Western Nigeria
}

\author{
Onipede Wusu \\ Department of Sociology \\ Lagos State University \\ Ojo, Lagos \\ onipedewusu@vahoo.com
}

DOI: 10.36108/NJSA/9002/70(0130)

Vol. 7 Issue 1, 2009

\begin{abstract}
Total fertility rate in Nigeria is 5.7 compared with over 8 in the past. Modern contraceptive use within marriage is very low and socio-economic development is still crawling. What factors account for this fragile transition? This question is the focus of this study. The study examines the socioeconomic and cultural factors that account for fertility transition in the country. Data were gathered through a survey conducted among the Ogu of south-western Nigeria. Analysis employed descriptive statistical tools and Ordinary Least Square model. Analysis reveals that post primary education (especially among women), spousal discussion about family size, monogamous marriage and age at first marriage were inversely related to children ever born (CEB) among men and female respondents. The result suggests that moderate improvement in these factors are likely responsible for the fragile transition. Therefore, policies to raise literacy level especially among women, increase age at first marriage, promote monogamous marriage and spousal communication may accelerate the fragile transition in the country.
\end{abstract}

Key words: fertility, contraceptive use, fertility transition, ideal family size, Ogu

\section{Introduction}

Demographic literature has indicated that fertility is declining in almost all regions of the world and the rates of the decline had been more rapid than expected in some regions (Bongaarts, 2008). Sub-Saharan Africa is not left out of this development (Caldwell, Orubuloye and Caldwell, 1992; Codjoe, 2007). However, the pace of fertility transition in most countries in the region is reported to have been slower (Kirk and Pillet, 1998) and even stagnant in some countries (Bongaarts, 2008). In Nigeria, fertility decline was reported in the 1990s (Orubuloye, 1995). The decline was reported for the southern part of the country (Caldwell, Orubuloye and Caldwell, 1992). Smith (2004) described the transition as a very slow one and Bongaarts (2006) implicitly grouped the country among those with serious stalled fertility decline. The Total Fertility Rate (TFR) is still as high as 5.7 (Population Reference Bureau, 2009). It appears it is not certain when the slow decline will start again and eventually attain replacement level (Smith, 2004; Bongaarts, 2006). 
This could be predicated upon two interrelated theoretical grounds. In the first place, all over the world fertility decline is mostly irreversible if it is engineered by consistent birth regulation within marriage (Cleland, Onuoha and Timaeus, 1994). This is not the case in Nigeria where contraceptive use remains very low. Estimate of modern contraceptive use by married women in Nigeria is as low as 8 percent (PRB, 2008). This implies that fertility regulation in marriage is limited in the country. The situation casts doubt on the prospects of the reported fragile transition (which has stagnated). Caldwell and Caldwell (2000) had earlier on reflected upon this situation and observed that TFR of about 6 is an evidence of the non-existence of any significant level of family size control.

Secondly, improving socio-economic development is also a crucial driving force in fertility transition (Bongaarts, 2006, 2008). Socio-economic development in Nigeria is still crawling. However, TFR of 5.7 may be considered as a significant step towards transition if compared to 8 or more in the past (Orubuloye, 1999). The question that has not been adequately addressed in the literature is what are the factors that account for this apparently slight but important decline in fertility in the country? This paper, using a survey data generated among the $O g u$ of south-western Nigeria, seeks to highlight the factors that propelled the fragile or slight fertility transition that has been reported in view of the crawling socio-economic development situation and very low modern contraceptive use (Smith, 2004)?

The literature shows that the factors that have sustained high fertility in the country, as in other West African countries include kinship institution and other social structures, economic, and cultural forces (Isiugo-Abanihe, 1994; Makinwa-Adebusoye, 1994, Caldwell and Caldwell, 2000; Smith, 2004; Nwakeze, 2007; Codjoe, 2007). Illuminating factors other than modern contraceptives and socio-economic development that are motivating recent changes in fertility in the country is an important research goal. This article seeks to contribute in this direction. It uses a micro data set collected in 2003 to examine the factors among $O g u$ married men and women of south-western Nigeria.

\section{Methods}

Data were sourced through a sample survey conducted among the Egun speaking people in Nigeria, late 2003. The location of the study covered settlements largely inhabited by the people (the $O g u$ ). They are found in major concentrations in Badagry local government area of Lagos State and the Ipokia and Ado-Odo local government areas of Ogun State. The Ogu constitute one of the minority groups in Nigeria. They are also found in most of the West African countries viz., Benin Republic, Togo and Ghana.

The study employed a multistage sampling procedure to gather a sample of 889 married men and women. This procedure enabled the researcher to generate a list of towns and villages in the study setting. Badagry Township was the only urban settlement where four of the eight quarters were randomly 
selected and four of the major streets in each of the selected quarters were also chosen. In the chosen streets a census of the buildings was taken and buildings were systematically chosen. In each building selected, households were picked through a simple random process and eligible male and female respondents were interviewed separately. In rural settlements which were typically hamlets, the procedure included all the buildings in the sampling frame. At this level, one household was selected and eligible men and women were separately interviewed.

The main dependent variable - fertility-was measured using children ever born (CEB). Ideal family size was also measured to assess fertility preference in the population. The ideal family size concept was considered an important variable on the ground that it is a good reflection of the willingness of a society to either adopt modern fertility behaviours or retain traditional childbearing practices. Children ever born and ideal family size were measured through the following questions in the questionnaire administered in the sample population: How many children has God blessed you with? How many male/female children? And in your opinion, how many children would you regard acceptable for a couple to have in this community?

Analysis was carried out at univariate, bivariate and multivariate levels. At the univariate level, socio-demographic and economic characteristics of respondents are described. Descriptive statistics were used to describe the dependent variables in terms of the identified socio-economic characteristics at the bivariate level. Multivariate analysis involves the construction of the Ordinary Least Square (OLS) regression models to explain fertility behaviour in the population. In the regression models, the independent variables were entered as dummy variables.

\section{Results}

Socio-demographic characteristics of respondents

Table 1 shows the basic socio-economic and cultural backgrounds of the sample population. The sample included 49.5 percent of males and 50.5 percent of females. The average age of male respondents was 38.2 while that of their female counterparts was 33.5. About 46 percent and 54 percent of the sample were located in rural and urban places of residence, respectively. The distribution of the respondents by education reflects that the majority of them have had some formal education. The average number of years of schooling among men was almost eight whereas among their female counterparts it was 6.2. In the sample only 12 percent of male respondents and 24 percent of their female counterparts had not had any formal schooling. The religious affiliation of the respondents indicates that the majority of both male and female respondents were Protestants (59.5 percent of male and 68.2 percent of females). 
The occupational distribution of the sample reveals that the majority were self employed. More of men were engaged in agriculture-related occupations (30.2 percent) while their female counterparts were mostly housewives (36.7 percent) and 20.7 percent engaged in petty trading. Marriage type indicates that monogamy (70.6 percent among males and 76.8 percent among females) was more prevalent. Generally, age at first marriage was stable, but it is relatively lower among women $($ mean $=20.5)$ than their male counterparts $($ mean $=24.2)$.

Table 1: Percentage Distribution of Respondents by selected sociodemographic characteristics and mean values, by sex

\begin{tabular}{|l|c|c|}
\hline \multirow{2}{*}{ Characteristics } & Male & Female \\
\cline { 2 - 3 } Current Age & $\mathrm{N}=440$ & $\mathrm{~N}=449$ \\
\hline 20 & & \\
$20-24$ & 10.9 & 20.3 \\
$25-29$ & 14.3 & 14.6 \\
$30-34$ & 29.0 & 30.0 \\
$35-39$ & 21.6 & 11.8 \\
$40-44$ & 11.0 & 9.9 \\
$45+$ & 8.0 & 7.6 \\
Mean age & 5.2 & 5.8 \\
\hline Education level & 38.19 & 33.47 \\
No schooling & & \\
Primary & 12.0 & 24.3 \\
Secondary & 35.0 & 31.8 \\
Post secondary & 32.3 & 30.3 \\
Mean years of schooling & 20.7 & 13.6 \\
\hline Religious Affiliation & 7.75 & 6.23 \\
Catholic & & \\
Protestants & 13.4 & 13.4 \\
Muslim & 59.5 & 68.2 \\
Traditionalist & 10.2 & 8.5 \\
\hline
\end{tabular}




\begin{tabular}{|l|c|c|}
\hline Occupation & & \\
Housewife/unemployed & 15.2 & 36.7 \\
Agric/Fishing & 30.2 & 16.7 \\
Petty Trading & 8.6 & 20.7 \\
Private Business & 26.8 & 14.3 \\
Government Worker & 19.1 & 11.6 \\
\hline Income Level & & \\
$\leq 5000$ & 40.2 & 55.9 \\
5001-10,000 & 29.8 & 24.7 \\
10,001-15,000 & 14.5 & 10.5 \\
15,0001+ & 15.5 & 8.9 \\
Mean & 12,232 & 7,152 \\
\hline Marriage Forms & & \\
Monogamy & 70.7 & 76.8 \\
Polygyny & 4.1 & 6.2 \\
Divorced/Separated & 21.3 & 12.9 \\
Widowed & 3.9 & 4.1 \\
\hline Age at first Marriage & & \\
<15 & 21.1 & 25.8 \\
15-19 & 15.9 & 22.5 \\
20-24 & 21.1 & 29.0 \\
25-29 & 36.4 & 21.8 \\
30+ & 5.5 & 0.9 \\
Mean at first marriage & 24.2 & 20.5 \\
\hline
\end{tabular}

\section{Correlates of Fertility}

(i) Bivariate Analysis

Table 2 shows the average children ever born and ideal family size reported by respondents with respect to selected characteristics. In general, the average number of children ever born reported by male respondents was higher than that of their female counterparts. Average number of children ever born reported by both categories of respondents is relatively higher in rural areas. Male respondents CEB are 5.2 and 4.1 in rural and urban areas respectively, and 3.7 (rural) and 3.2 (urban) for their female counterparts. The Table reveals that there exists a fairly direct relationship between age and children ever born reported by both male and female respondents. Among male respondents, CEB was highest for age 35 and above while it ranged between 3.6 and 5.4 for other age groups. On the other hand it ranged between 2.8 and 4.5 among their female counterparts. 
Table 2: Average children ever born and ideal family size reported by respondents with respect to selected characteristics

\begin{tabular}{|c|c|c|c|c|}
\hline \multirow[t]{2}{*}{ Characteristics } & \multicolumn{2}{|c|}{$\begin{array}{l}\text { Male } \\
\text { Mean }\end{array}$} & \multicolumn{2}{|c|}{$\begin{array}{c}\text { Female } \\
\text { Mean }\end{array}$} \\
\hline & CEB & Ideal & CEB & Ideal \\
\hline $\begin{array}{l}\text { Place of residence } \\
\text { Rural } \\
\text { Urban } \\
\end{array}$ & $\begin{array}{l}5.2 \\
4.1 \\
\end{array}$ & $\begin{array}{l}3.5 \\
4.9 \\
\end{array}$ & $\begin{array}{l}3.7 \\
3.2 \\
\end{array}$ & $\begin{array}{l}3.6 \\
4.9 \\
\end{array}$ \\
\hline $\begin{array}{l}\text { Current age } \\
<20 \\
20-24 \\
25-29 \\
30-34 \\
35+\end{array}$ & $\begin{array}{l}3.6 \\
4.0 \\
3.8 \\
5.4 \\
6.7\end{array}$ & $\begin{array}{l}4.2 \\
4.6 \\
3.8 \\
3.7 \\
4.2\end{array}$ & $\begin{array}{l}2.8 \\
4.5 \\
3.5 \\
4.5 \\
4.1\end{array}$ & $\begin{array}{l}4.0 \\
4.3 \\
4.5 \\
3.9 \\
4.3\end{array}$ \\
\hline $\begin{array}{l}\text { Education level } \\
\text { No schooling } \\
\text { Primary } \\
\text { Post primary } \\
\end{array}$ & $\begin{array}{l}5.2 \\
5.1 \\
3.0 \\
\end{array}$ & $\begin{array}{l}4.6 \\
5.7 \\
3.7 \\
\end{array}$ & $\begin{array}{l}4.0 \\
3.8 \\
3.2 \\
\end{array}$ & $\begin{array}{l}3.7 \\
4.8 \\
3.7 \\
\end{array}$ \\
\hline $\begin{array}{l}\text { Family structure } \\
\text { Extended } \\
\text { Nuclear } \\
\text { Single parent }\end{array}$ & $\begin{array}{l}4.8 \\
4.0 \\
5.2\end{array}$ & $\begin{array}{l}4.0 \\
4.2 \\
4.3 \\
\end{array}$ & $\begin{array}{l}3.5 \\
3.7 \\
5.4\end{array}$ & $\begin{array}{l}4.1 \\
4.3 \\
4.5\end{array}$ \\
\hline $\begin{array}{l}\text { Discuss about family size } \\
\text { Yes } \\
\text { No }\end{array}$ & $\begin{array}{l}4.0 \\
4.8 \\
\end{array}$ & $\begin{array}{l}4.0 \\
4.2 \\
\end{array}$ & $\begin{array}{l}3.7 \\
4.0 \\
\end{array}$ & $\begin{array}{l}4.1 \\
4.5 \\
\end{array}$ \\
\hline $\begin{array}{l}\text { Age at first Marriage } \\
<20 \\
20-24 \\
25-29 \\
30+ \\
\end{array}$ & $\begin{array}{l}6.8 \\
5.5 \\
3.6 \\
3.4 \\
\end{array}$ & $\begin{array}{l}4.8 \\
3.8 \\
3.1 \\
3.0\end{array}$ & $\begin{array}{l}5.8 \\
5.1 \\
3.2 \\
3.3 \\
\end{array}$ & $\begin{array}{l}4.5 \\
4.1 \\
4.0 \\
4.0\end{array}$ \\
\hline $\begin{array}{l}\text { Marriage forms } \\
\text { Monogamy } \\
\text { Polygyny } \\
\text { Not currently married* }\end{array}$ & $\begin{array}{l}4.1 \\
6.1 \\
4.0 \\
\end{array}$ & $\begin{array}{l}4.0 \\
4.8 \\
4.1 \\
\end{array}$ & $\begin{array}{l}3.8 \\
4.0 \\
3.5 \\
\end{array}$ & $\begin{array}{l}4.1 \\
4.0 \\
3.3 \\
\end{array}$ \\
\hline
\end{tabular}

CEB - average children ever born Ideal - average ideal family size

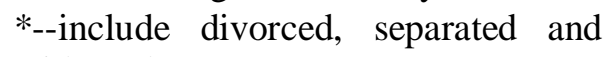
widowed

The average number of children ever born declined with improvement in educational attainment. Male and female respondents who indicated post primary schooling reported the lowest average of 3.0 and 3.2 respectively. In 
the same vein, respondents who had not gone through any formal schooling reported the highest average children ever born (male $=5.2$; female $=4.0$ ). Among both male and female respondents, the practice of frequent spousal discussion about family size was associated with relatively lower family size. While the average family size for those who practised regular discussion were 4.0 and 3.7 for male and female respondents respectively, that of their counterparts who did not regularly discuss with their partners were 4.8 and 4.0 respectively. Among both male and female respondents, children ever born were generally higher among those who married early. The relationship between marriage form and children ever born shows that polygynous homes account for the highest average children ever born among the respondents.

Table 2 also shows the average family size considered ideal in the study population vis-à-vis average children ever born. Urban men (4.9) and women (3.2) reported a lower ideal family size compared with that of their rural counterparts. Relationship between educational attainment and ideal family size shows that respondents with post primary schooling indicated the least ideal family size of 3.7 among female respondents. But among male respondents, average ideal family size for those with primary schooling was higher (with 1.1) than no schooling. Across various characteristics among male respondents, the average ideal family size ranges between 3.7 and 4.6 while it ranged between 3.9 and 4.5 among female respondents.

\section{(ii) Multivariate Analysis}

Table 3 and 4 display the coefficients for males and females Ordinary Least Square models. In Table 3, spousal discussion about family size, marriage form, age at first marriage and current age were significant correlates of children ever born among males. Spousal discussion about family size was inversely related to CEB. Monogamous couples (-5.31) and not currently married (-3.12) were negatively related to CEB compared to those who were in polygynous unions. While age at first marriage was inversely related, current age was positively related to CEB.

In the female model, education, marriage forms, age at marriage, current age and spousal discussion about family size were significantly related to children ever born. According to the Table, among female respondents, post primary schooling reduced the level of CEB by 0.65 while primary education increased CEB by 0.48 compared to no schooling. Monogamy (-6.53) and not currently married (-5.15) were inversely related to CEB compared to polygyny. Age at first marriage and current age were also negatively related to CEB among female respondents. This denotes the higher the age at first marriage the lower the number of children ever born. 
Table 3: OLS regression coefficient of children ever born, by selected characteristics

\begin{tabular}{|c|c|c|c|c|c|c|}
\hline \multirow{2}{*}{ Characteristics } & \multicolumn{3}{|c|}{ Male model } & \multicolumn{3}{|c|}{ Female model } \\
\hline & Coefficient & S.E & $\mathbf{T}$ & Coefficient & S.E & $\mathbf{T}$ \\
\hline $\begin{array}{l}\text { Family structure } \\
\text { Nuclear } \\
\text { Extended (rc) }\end{array}$ & $\begin{array}{l}-0.27 \\
-\end{array}$ & 0.43 & $\begin{array}{r}-0.64 \\
-\end{array}$ & $\begin{array}{l}-0.45 \\
-\end{array}$ & 0.26 & $\begin{array}{r}-1.76 \\
-\end{array}$ \\
\hline $\begin{array}{l}\text { Education } \\
\text { Primary } \\
\text { Post primary } \\
\text { No schooling (rc) } \\
\end{array}$ & $\begin{array}{l}0.75 \\
-0.07 \\
- \\
\end{array}$ & $\begin{array}{c}0.64 \\
0.65\end{array}$ & $\begin{array}{r}1.18 \\
-0.11\end{array}$ & $\begin{array}{l}0.48 \\
-0.65^{*} \\
- \\
\end{array}$ & $\begin{array}{c}0.33 \\
0.32\end{array}$ & $\begin{array}{r}1.47 \\
-2.02\end{array}$ \\
\hline $\begin{array}{l}\text { Discuss family size } \\
\text { Yes } \\
\text { No }(\mathrm{rc})\end{array}$ & $\begin{array}{l}-1.62 * * \\
- \\
\end{array}$ & 0.46 & -3.51 & $\begin{array}{l}-0.16 \\
- \\
\end{array}$ & 0.28 & -0.58 \\
\hline $\begin{array}{l}\text { Marriage form } \\
\text { Monogamy } \\
\text { Polygyny (rc) } \\
\text { Not currently married }\end{array}$ & $\begin{array}{l}-5.31 * * \\
- \\
-3.12 * *\end{array}$ & $\begin{array}{l}1.01 \\
0.12\end{array}$ & $\begin{array}{r}-2.87 \\
- \\
-6.52\end{array}$ & $\begin{array}{l}-6.53 * * \\
- \\
-5.15 * *\end{array}$ & $\begin{array}{l}0.60 \\
0.66\end{array}$ & $\begin{array}{r}-10.83 \\
- \\
-7.78\end{array}$ \\
\hline Age at first marriage & $-0.17 * *$ & 0.03 & -6.52 & $-0.05^{* *}$ & 0.16 & -3.32 \\
\hline Current age & $0.04 *$ & 0.02 & -3.51 & $-0.03 *$ & 0.01 & -0.58 \\
\hline $\begin{array}{l}\text { Constant } \\
\text { R square } \\
\text { F ratio } \\
\text { (N) }\end{array}$ & $\begin{array}{l}7.91 \\
0.46 \\
45.19^{* *} \\
(439)\end{array}$ & & & $\begin{array}{l}7.75 \\
0.37 \\
31.87 * * \\
(448)\end{array}$ & & \\
\hline
\end{tabular}

* - Significant at $\mathrm{P}<0.05 \quad * *$ - Significant at $\mathrm{P}<0.01 \quad$ rc-reference category

In table 4, age at first marriage was inversely related to ideal family size among male respondents. Among their female counterparts, education and age at first marriage were significantly related to the dependent variable. Post primary schooling (-1.02) and age at first marriage (-0.04) were inversely related to ideal family size. 
Table 4: OLS regression coefficients of ideal family size, by selected characteristics

\begin{tabular}{|c|c|c|c|c|c|c|}
\hline \multirow[t]{2}{*}{ Characteristics } & \multicolumn{3}{|c|}{ Male model } & \multicolumn{3}{|c|}{ Female model } \\
\hline & Coefficient & S.E & $\mathbf{T}$ & Coefficient & S.E & $\mathbf{T}$ \\
\hline $\begin{array}{l}\text { Family structure } \\
\text { Nuclear } \\
\text { Extended (rc) }\end{array}$ & $\begin{array}{l}0.24 \\
-\end{array}$ & 0.29 & $\begin{array}{l}0.04 \\
-\end{array}$ & $\begin{array}{l}-0.12 \\
-\end{array}$ & 0.22 & $\begin{array}{l}-0.55 \\
-\end{array}$ \\
\hline $\begin{array}{l}\text { Education } \\
\text { Primary } \\
\text { Post primary } \\
\text { No schooling (rc) }\end{array}$ & $\begin{array}{l}-0.01 \\
-0.69 \\
-\end{array}$ & $\begin{array}{l}0.44 \\
0.43\end{array}$ & $\begin{array}{l}-0.13 \\
-0.60 \\
-\end{array}$ & $\begin{array}{l}-0.31 \\
-1.02 * * \\
-\end{array}$ & $\begin{array}{l}0.28 \\
0.26\end{array}$ & $\begin{array}{l}-1.13 \\
-3.88 \\
-\end{array}$ \\
\hline $\begin{array}{l}\text { Marriage form } \\
\text { Monogamy } \\
\text { Polygyny (rc) } \\
\text { Not currently married } \\
\end{array}$ & $\begin{array}{l}0.04 \\
- \\
0.78 \\
\end{array}$ & $\begin{array}{l}0.69 \\
0.75 \\
\end{array}$ & $\begin{array}{l}0.01 \\
- \\
1.04 \\
\end{array}$ & $\begin{array}{l}0.51 \\
- \\
1.05 \\
\end{array}$ & $\begin{array}{l}0.51 \\
0.57 \\
\end{array}$ & $\begin{array}{l}0.99 \\
- \\
1.85 \\
\end{array}$ \\
\hline Age at first marriage & $-0.062^{*}$ & 0.17 & -3.56 & $-0.04 * *$ & 0.01 & -2.88 \\
\hline Current age & 0.03 & 0.12 & 2.39 & 0.02 & 0.01 & 1.31 \\
\hline $\begin{array}{l}\text { Constant } \\
\text { R square } \\
\text { F ratio } \\
\text { (N) }\end{array}$ & $\begin{array}{l}4.45 \\
0.07 \\
4.47 * * \\
(439)\end{array}$ & & & $\begin{array}{l}4.50 \\
0.09 \\
5.86^{* *}\end{array}$ & & \\
\hline & & & $\begin{array}{l}\text { ign } \\
\text { Sig } \\
\text { efe }\end{array}$ & $\begin{array}{l}\text { it at } \mathrm{P}<0 \\
\text { int at } \mathrm{P}<0 \\
\text { category }\end{array}$ & & \\
\hline
\end{tabular}

\section{Discussion}

Fragile fertility decline was reported for Nigeria in mid-1990s (Orubuloye, 1995). It is pertinent to note that this decline emerged in the face of very low use of effective contraceptive and crawling socio-economic development contrary to established pattern in demographic literature. It is as a result of this contradiction that this study chose to examine factors that drove the transition even though it was fragile and has stagnated. The average number of children ever born was examined as a measure of fertility while fertility preference which is an important variable in fertility behaviour was measured by estimating ideal family size in the study population. Limitations of these measures are discussed later in this section.

At the level of bivariate analysis, the data demonstrated that the majority of the respondents reported lower number of children ever born. The average number of children ever born ranges between 3.9 and 6.8 in the study population. The average ideal family size reported by the respondents (between 3.5 and 4.9) indicates that fertility preference in the study population is on the path of decline. By extension it is suggesting the gradual emergence of 
demographic innovators if we compare the values with average family size of over 8 in the past (Orubuloye et al., 1999). The study demonstrates the gradual assimilation of modern reproductive attitudes that should heralds, all things being equal, the beginning of sustainable fertility transition, as indicated by what the respondents considered as ideal family size.

More importantly, the Ordinary Least Square models on the two variables provide better ground for discussion on the possibility of sustainable fertility transition in the study population. The independent variables included in both male and female models account for 46 percent and 37 percent respectively, of the variations in children ever born. These models appear relatively satisfactory. Though the explanatory power of models in table 4 is weak judging from the fact that the $\mathrm{R}$ squares were only 0.07 and 0.09 , the fact that the $\mathrm{F}$ ratios were statistically significant suggests that the models are still relevant. According to the regression coefficients, in male models spousal discussion about family size, age at first marriage, marriage form and current age were significantly related to children ever born. On the other hand, among their female counterparts, education, marriage form, age at first marriage and current age are significant explanatory variables of children ever born. Key in this result is the fact that with the exception of current age (among men), an inverse relationship was observed between these independent variables and the number of children ever born among both male and female respondents. Similar finding has been reported in Nepal (Adhikari, 2010).

Monogamous marriages and age at first marriage of about 30 or above are very crucial factors in family size decline. In other words polygynous marriage is an important factor sustaining high fertility in the past. This finding also suggests that the traditional family structure that has been described as a factor keeping fertility on the high side (Fapounda and Todaro, 1988) is giving way. In this study population it has been described that although it is still largely extended in structure but implicit changes are taking place that do not support the old large family size norm (Caldwell, Orubuloye and Caldwell, 1992; Wusu and Isiugo-Abanihe, 2006). Delay in marriage is expected to bring down fertility because it means reducing the time spent in marriage thus limiting exposure to the risk of childbearing. It also implies delay in childbirth in a setting where childbirth closely follows marriage.

In addition, monogamy and late marriage are likely to be dependent upon educational attainment which is an important variable with negative effect on fertility among female respondents. In the study population, the level of basic education has improved substantially owing to several years of free education policy in western Nigeria. Education affects every area of human life, modernises attitudes and gives access to information. Relatively higher educational attainment is expected to result into modern reproductive goals and ultimately produce demographic innovators in the society, especially among women. In addition, education raises people's aspirations. Such aspirations are generally not compatible with large family size. Education individuals are usually open to innovation and have access to information on how to manage 
their reproductive life to achieve desired family size. This is consistent with the findings of earlier studies (for instance, Babalola, 1992; Orubuloye, 1995; Feyisetan et al., 2000; Caldwell and Caldwell, 2000; Lloyd et al., 2000).

Ideal family size is an important indicator of the type of reproductive attitude prevailing in a social setting. The influence of age on ideal family size in bivariate analysis suggests that the gradual emergence of modern reproductive attitudes is permeating the study population. The realisation of the benefits of small family size norm cuts across all categories of the population. In fact, in view of the impact of spousal communication on ideal family size, it is clear that this norm is gradually permeating the society: that is, even among couples who do not engage in regular spousal communication. This situation may not be unconnected with the rising emphasis of wealth flow from parents to children rather than from children to parents as was the case in the past. It is apparent in the multivariate section that education and age at first marriage portend great channels of infiltration, especially the female folk in the society, with reproductive attitude consistent with declining fertility. This finding is consistent with that of a recent study in Ethiopia (Worku and Alene, 2008).

The study suffers from a number of problems. The first has to do with the age distribution of the respondents which show that a good proportion belongs to relatively younger age group. This limitation might have affected the family size reported and the fertility analysis undertaken here and, to a large extent, may not represent the older generation. Another shortcoming of the study centres on the fertility measure adopted - children ever born. The measure is prone to generating underestimated or over-estimated fertility level (Adhikari, 2010). Owing to the fact that the measure is sensitive to large children ever born, a few respondents with large children ever born might have influenced the reported CEB leading to high fertility estimate. It is also possible for respondents to have underreported and over-reported the number of children ever born as a result of memory loss since they have to call back the number of children ever born. This may not be a serious problem since pay-off is possible. Also, although ideal family size is widely used as an indicator for fertility preference, it usually suffers from biases owing to rationalization and nonresponse (Bongarrts, 2006) which must have affected the result here.

An apparent limitation is the exclusion of contraceptive use as an independent variable. This becomes important in view of the subject of the study - fertility behaviour. However, given that the objective of this study was to examine other factors driving fertility decline in low contraceptive prevalent settings. Its exclusion is deliberate and may not be regarded a serious omission. Finally, the bivariate analysis did not involve the use of any statistical technique to test the level of association. It dwells mainly on association based on interaction between selected independent variables and the average children ever born in each category. In spite of these limitations, the findings are quite 
insightful and some far reaching conclusions with sound policy implications are drawn in the next section.

\section{Conclusion}

All over the world fertility decline is mostly irreversible if only it is sponsored by widespread use of contraceptives within marriage (Cleland, Onuoha and Timaeus, 1994; Bongaarts, 2006). In this study population, as it is all over the country, modern contraceptive use within marriage is very low (discussed in Wusu and Isiugo-Abanihe (2007). Yet some kind of fertility decline existed in the past (Orubuloye, 1995) - it has now stalled (Bongaarts, 2008). It is likely that the fragile decline was driven by some other factors. Given that considerable decline in infant mortality and child death that motivated high fertility in pre-modern age are taken for granted (Feyisetan and Casterline, 2000), this study suggests that gradual improvement in literacy rate (especially among women), decline in the prevalence of polygynous marriages and early marriage, and increasing practice of spousal communication are the factors powering the decline. Investing more in qualitative education, especially female schooling, is likely to motivate adoption of sustainable modern fertility practices. It is also likely that by this strategy, barriers to modern contraceptive use identified in Campbell et al (2006) shall be conquered and modern fertility regulation accelerated.

Finally it may be possible to attain fertility decline below biological maximum without contraceptives but it is virtually impossible to actualize and sustain low fertility (about replacement level) in the absence of substantial increase in use of effective birth control by married couples (Weeks, 2002; Bongaarts, 2008). It is therefore imperative for government and nongovernmental organisations to invest more in breaking down the barriers to contraceptive use in the society. It may also be necessary to adopt a more serious family planning policy that is capable of enforcing wide spread use of modern contraceptives and promote more innovative reproductive health behaviour (Wusu, 2009).

\section{References}

Adhikari, R. 2010. Demographic, socio-economic, and cultural factors affecting fertility differentials in Nepal. BMC Pregnancy and Childbirth, vol.10:19-20.

Babalola, O. S. 1992. The Effects of Urbanisation on fertility in Southwest Nigeria: The Explanatory Role of the Proximate Fertility Variables. UAPS Study Report, No. 3.

Bankole, S. A. 1992. Marital Partners' Reproductive Attitudes and Fertility among the Yoruba of Nigeria. A Ph.D. Dissertation in Demography, University of Pennsylvania.

Bongaarts, J. 2006. The Causes of Stalling Fertility Transition. Studies in Family Planning, vol. 27(1):1-16. 
Bongaarts, J. 2008. Fertility transitions in developing countries: Progreess or stagnation? Studies in Family Planning, vol.39 (2): 105-110.

Boroffice, O. B. 1995. Women's Attitudes to Men's Sexual Behaviour. Health Transition Review (supplement) vol. 5, 67-79.

Caldwell, J. C.; Orubuloye, I. O. and Caldwell, P. 1992. Fertility Decline in Africa: A New Kind of Fertility Transition. Population and Development Review, vol. 18 (2): 211-242

Caldwell, J. and Caldwell P. 2000. The limitation of family size in Ibadan, Nigeria: An explanation of its comparative rarity derived from in-depth interviews. In Ebigbola, J.A and Renne, E.D. (eds.): Population and Development Issues: Ideas and Debates. Ibadan: African Book Builders, pp. $126-171$.

Campbell, M.; Sahin-Hodoglugil, N. N. and Potts, M. 2006. "Barriers to fertility Regulation: A Review of the literature". Studies in Family Planning, vol.37 (2): 87-98.

Cleland, J., Onuoha, N. and Timaeus, I. 1994. Fertility Change in Sub-Saharan Africa: a Review of the Evidence, in Loch, T. and Hertrich (eds.) The onset of Fertility transition in Sub-Saharan Africa. Belgium: IUSSP: 1-20.

Codjoe, S. N. A. 2007. The Role of Proximate and other Determinants in Ghana's Fertility Transition. African Population Studies, vol.22(2): 127146.

Fapounda, R. E. and Todaro, P. M. 1988. Family structure, implicit contracts, and the demand for children in Southern Nigeria. Population and Development Review, vol. 14 (4): 571-594.

Feyisetan, B. J.; Oyediran, A. K. and Ishola, P. G. 2000. Information, Education and Counselling and the participation of men in Family Planning. In Ebigbola, J.A. and Renne, E.P. (eds.) Population and Development Issues: Ideas and Debates. Ibadan: African Book Builders, pp. $201-224$.

Feyisetan, B. and Casterline, J. B. 2000. Fertility preferences and contraceptive change in developing countries. International Family Planning Perspectives, vol 26 (3): 100-109.

Isiugo-Abanihe, U. C. 1994. Parenthood in Sub-Saharan Africa: child fostering and its relationship with fertility. In Loch, T. and Hertrich (eds.) The onset of Fertility transition in Sub-Saharan Africa. Belgium: IUSSP: 163-174.

Kirk, D. and Pillet, B. 1998. "Fertility levels, trends, and differentials in SubSaharan Africa in the 19980s and 1990s". Studies in Family Planning. Vol. 29 (1): 1-22.

Lloyd, B.; Cynthia, K. E. C. and Hewett, P. 2000. The spread of Primary Schooling in Sub-Saharan Africa: Implications for Fertility Change. Population and Development Review. Vol. 26 (3): September. Pp. 483 515. 
Makinwa-Adebusoye, P. 1994. "Changes in the costs and benefits of children to their parents", in Loch, T. and Hertrich (eds.) The onset of Fertility transition in Sub-Saharan Africa. Belgium: IUSSP: 175-192.

Mason, O. K. 2001. Gender and Family Systems in the Fertility Transition. Population and Development Review (A supplement), vol. 27, PP 160-179.

Nwakeze, N. M. 2007. The Demand for Children in Anambra State of Nigeria: A Logit Analysis. African Population Studies, vol. 22(2): 167-191.

Orubuloye, I. O. 1995. The Demographic situation in Nigeria and Prospects for Fertility Transition: Journal of International Development, 7(1):135 - 144.

Orubuloye, I. O. and Oguntimehin, F. 1999. Men's Perspectives on Fertility, Sexuality, Contraception, Sexually Transmitted Diseases and AIDS in Ekiti, Southwest Nigeria. African Population in the $21^{\text {st }}$ Century. Proceedings of UAPS Conference, vol. 3: 53 - 68.

Oyediran, K. A. 2002. Spousal Communication and Fertility Behaviour Among the Yoruba of South-western Nigeria: The Case of Ogbomoso and Iseyin. A Ph.D Dessertation in the Department of Sociology, University of Ibadan.

Population Reference Bureau. 2009. World population data sheet. www.prb.org (Accessed 15th of December, 2010).

Smith, D. J. 2004. Contradictions in Nigeria's fertility transition: The burdens and benefits of having people. Population and development review, vol. 30 (2): 221-238.

Worku, A. and Alene, G. D. 2008. Differentials of fertility in North and South Gondarzones, Northwest Ethiopia: A Comparative Cross-sectional Study. BMC Public Health, vol. 8: 397-409.

Wusu, Onipede and Isiugo-Abanihe, Uche C. 2006. Interconnections among changing family structure, childrearing and fertility behaviour among the Ogu, Southwestern Nigeria. Demographic Research, vol. 14: 139-156.

------- 2007. "Gap in Knowledge and Use of Contraceptives in SouthWestern Nigeria: A Study of the Ogu. UNILAG Sociological Review, $v$ ol. 8: 83-106.

Wusu, Onipede 2009. In-decisive population policy and socioeconomic development in Nigeria. A paper presented at the 2009 Faculty of Social Sciences Annual Conference, Lagos State University, Ojo, 23rd- 25th of April, 2009. 